\title{
Profesor Bogdan Gregor - naukowiec i nauczyciel akademicki
}

\section{Przebieg kariery zawodowej i naukowej}

Profesor dr hab. Bogdan Gregor urodził się w 22 listopada 1943 roku w Porażynie w województwie wielkopolskim. Wyższe studia ukończył w roku 1966 i uzyskał tytuł magistra ekonomii na Wydziale Handlowo-Towaroznawczym Wyższej Szkoły Ekonomicznej w Poznaniu. Tam też rozpoczął pracę zawodową jako asystent stażysta, a następnie asystent. W roku 1968 został przeniesiony służbowo na Uniwersytet Łódzki na Wydział Ekonomiczno-Socjologiczny. Do roku 1971 pracował jako asystent i starszy asystent w Katedrze Ekonomiki Handlu na tym wydziale. W roku 1971 obronił pracę doktorską pt. Rynek artykutów do produkcji rolnej $w$ regionach uprzemysławianych napisaną pod kierunkiem naukowym prof. dr. hab. Jerzego Dietla. Została ona uhonorowana nagrodą Ministra Szkolnictwa Wyższego. Od 1971 do 1988 roku pracował jako adiunkt w Katedrze Ekonomiki Handlu, przekształconej w Instytut Obrotu Towarowego, a następnie w Katedrę Obrotu Towarowego. W roku 1987 obronił pracę habilitacyjną pt. Uwarunkowania i kierunki rozwoju ustug produkcyjnych dla rolnictwa. Od 1988 do 1990 roku pracował na stanowisku docenta na Wydziale Ekonomiczno-Socjologicznym UŁ, a od 1991 do 2002 roku na stanowisku profesora nadzwyczajnego (od 1994 roku na Wydziale Zarządzania wyodrębnionym z Wydziału Ekonomiczno-Socjologicznego). W grudniu 2002 roku uzyskał tytuł profesora nauk ekonomicznych i od roku 2004 do chwili obecnej pracuje na stanowisku profesora zwyczajnego w Uniwersytecie Łódzkim.

Profesor dr hab. Bogdan Gregor pełnił szereg odpowiedzialnych funkcji w Uniwersytecie Łódzkim - i tak w latach 1973-1980 był p.o. zastępcą dyrektora Instytutu Obrotu Towarowego, w latach 1983-1989 p.o. zastępcą kierownika Katedry Obrotu Towarowego, od 1992 roku do chwili obecnej jest kierownikiem Katedry Marketingu, a w jej ramach kierownikiem Zakładu Badań Marketingowych. W latach 1990-1993 sprawował funkcję prodziekana Wydziału Ekonomiczno-Socjologicznego, a w latach 1993-1994 dziekana tego Wydziału. Od 
1994 do 2002 roku i następnie od 2005 do 2008 roku pełnił funkcję dziekana Wydziału Zarządzania UŁ. W roku 2008 został wybrany prorektorem Uniwersytetu Łódzkiego ds. ekonomicznych i funkcję tę pełni do chwili obecnej.

Ponadto profesor dr hab. Bogdan Gregor pełnił inne funkcje w Uniwersytecie Łódzkim i poza nim. Zaliczyć do nich można:

- opiekun Studenckiego Koła Naukowego Ekonomiki Handlu UŁ (19711980);

- sekretarz naukowy Sekcji Łódzkiej Komitetu Badań Regionów Uprzemysłowionych PAN (1972-1980);

- członek Sekcji Produkcyjnej Obsługi Rolnictwa w Komitecie Organizacji Produkcji Rolnej i Wyżywienia Kraju PAN (1976-1978);

- od 1975 członek, a od 1977 do 1979 roku, sekretarz naukowy Komisji Organizacji Przestrzennej Obszarów Wiejskich w Komitecie Przestrzennego Zagospodarowania Kraju PAN;

- członek Zespołu Konsultacyjnego przy Zarządzie Wojewódzkiego Związku Spółdzielni Rolniczych „SCh” w Płocku (1977-1980) oraz w Skierniewicach (1978-1987);

- członek Sekcji III - Gospodarka Żywnościowa i Obsługa Rolnictwa w Komitecie Organizacji Produkcji Rolnej i Gospodarki Żywnościowej PAN (19781980);

- członek Sekcji Obrotu Rolniczego Komitetu Ekonomiki Rolnictwa PAN (1984-1987);

- członek Sekcji „Obrót i Przetwórstwo” Komitetu Ekonomiki Rolnictwa PAN (1987-1989);

- członek zespołu doradców prezesa Agencji Rynku Rolnego (1990-1993);

- ekspert Komisji Rolnictwa i Gospodarki Żywnościowej przy Senacie RP (1989-1993);

- z-ca przewodniczącego Rady Naukowej Ośrodka Promocji Biznesu „Ekorno” (1990-1994);

- członek Zespołu ds. Rynku Rolnego i Spółdzielczości w Radzie ds. Wsi i Rolnictwa przy Prezydencie RP (1992-1993);

- członek Rady Zarządzającej Polsko-Amerykańskim Centrum Zarządzania UŁ (1994 - do chwili obecnej);

- przewodniczący Rady Programowej studiów MBA (1995 - do chwili obecnej);

- z-ca redaktora naczelnego Redakcji Naukowo-Dydaktycznej „Folia Oeconomica" UŁ (1996 - do chwili obecnej);

- przewodniczący Zespołu Problemowego ds. Handlu przy Prezydencie m. Łodzi (2001); 
- współprzewodniczący Rady Biznesu przy Wydziale Zarządzania UŁ (2003 - do chwili obecnej);

- przewodniczący Uniwersyteckiej Komisji Finansowej Konferencji Rektorów Akademickich Szkół w Polsce od 2012 roku do chwili obecnej.

Należy podkreślić, że jako wieloletni dziekan Wydziału Zarządzania UŁ prof. dr hab. Bogdan Gregor przyczynił się w znaczący sposób do jego rozwoju. Wydział Zarządzania jest dzisiaj cenionym w kraju i za granicą ośrodkiem badań naukowych oraz kształcenia wysoko kwalifikowanych kadr menedżerskich. Już w pierwszych latach swego istnienia Wydział Zarządzania nawiązał rozległą współpracę międzynarodową. W kooperacji z Uniwersytetem Maryland (USA) utworzono Polsko-Amerykańskie Centrum Zarządzania z bogatą ofertą dydaktyczną (w tym m.in. prestiżowe w świecie studia MBA). Profesor dr hab. Bogdan Gregor ma ogromny wkład w budowę i oddanie do użytku w 2002 roku nowego gmachu Wydziału Zarządzania.

\section{Zainteresowania naukowo-badawcze}

Profesor dr hab. Bogdan Gregor jest znanym i cenionym autorytetem naukowym. Jego zainteresowania naukowo-badawcze dotyczyły początkowo problematyki rynku rolnego i handlu wiejskiego, a następnie marketingu. Obecnie koncentruje się na problematyce marketingu w świetle wyzwań zmieniającego się otoczenia i procesów globalizacyjnych oraz zastosowań nowych technologii informatycznych w handlu i marketingu. W ciągu ostatnich kilku lat podejmował badania naukowe dotyczące takich problemów, jak: e-commerce w sektorach B2B i B2C, marketing terytorialny oraz badania marketingowe.

Podczas pracy w Uniwersytecie Łódzkim prof. dr hab. B. Gregor wielokrotnie uzyskał zagraniczne stypendia naukowe i przebywał na stażach zagranicznych. Były to:

- stypendium badawcze Fundacji Humboldta (RFN) - łącznie 19 miesięcy (1980-1982);

- staż w Instytucie Ekonomicznym w Uniwersytecie w Roterdamie (Holandia - 1986);

- staże na Uniwersytetach w Mannheim i Giessen (RFN) - (1989, 1992, 1994, 1995, 1997);

- stypendium badawcze DAAD (RFN) - (1991);

- staż na Uniwersytecie w Pitsburgu (USA) - (1994); 
- staż na Uniwersytecie Karlsruhe (RFN) - (1995);

- staż na Uniwersytecie Maryland (USA) - (1994, 1997, 1999).

Godny podkreślenia jest dorobek naukowy prof. dr. hab. B. Gregora. Obejmuje on ponad 230 publikacji (w części we współautorstwie), w tym kilkanaście książek, a także kilkadziesiąt opracowań niepublikowanych. Do najważniejszych można zaliczyć publikacje książkowe: pt. E-Commerce, Oficyna Wydawnicza Branta, Bydgoszcz-Lódź 2002 (współautor M. Stawiszyński) oraz współautorstwo książek: pod red. H. Mruka pt. Analiza rynku, PWE, Warszawa 2003 i Marketing terytorialny pod red. Tadeusza Markowskiego, Polska Akademia Nauk, Komitet Przestrzennego Zagospodarowania Kraju, Warszawa 2006.

Za osiągnięcia naukowo-badawcze prof. dr hab. B. Gregor otrzymał dwie Nagrody Ministra (1972, 1999), Nagrodę Prezydenta m. Łodzi (1975), Nagrodę Sekretarza Naukowego PAN (1980), Nagrodę Rektora Akademii Ekonomicznej w Poznaniu (2004) oraz jedenaście Nagród Rektora UŁ (indywidualnych i zespołowych). Profesor dr hab. Bogdan Gregor był kierownikiem wielu projektów naukowo-badawczych.

\section{Dzialalność dydaktyczna i kształcenie młodej kadry naukowej}

Na szczególne podkreślenie zasługuje działalność dydaktyczno-wychowawcza i wkład prof. dr. hab. Bogdana Gregora w rozwój młodej kadry naukowej. Podczas pracy w Uniwersytecie Łódzkim pełnił on następujące funkcje:

- opiekun Studenckiego Koła Naukowego Ekonomiki Handlu (1971-1980), w uznaniu zasług na tym polu Jego nazwisko zostało wpisane do Złotej Księgi Międzynarodowego Studenckiego Ruchu Naukowego w Bratysławie (1978); otrzymał również Honorową Odznakę SZSP (1979) oraz „Medal za Zasługi dla Studenckiego Ruchu Naukowego" (1980);

- współautor eksperymentu dydaktycznego pod nazwą „Uczenie poprzez udział studentów w badaniach" (1983-1986);

- współautor programu studiów na kierunku „Zarządzanie i Marketing” (1989-1990);

- współautor programu studiów na specjalności i kierunku studiów „Marketing" (1990, 2007, 2012);

- współautor programu studiów MBA (polsko-amerykańskich - wspólnie z Uniwersytetem w Maryland w Stanach Zjednoczonych w 1994 i polsko-francuskich, wspólnie z Uniwersytetem Lyon III we Francji - 1992); 
- organizator i współautor programu Studiów Podyplomowych „Marketingowe Zarządzanie Firmą" (1992);

- autor programu bloku specjalizacyjnego e-Commerce (2003);

- wykładowca przedmiotów: „Analiza rynku” i „Badania marketingowe” na studiach dziennych magisterskich, MBA i studiach podyplomowych;

- autor i współautor: dwóch podręczników i jednego skryptu z zakresu badań rynkowych i marketingowych;

- promotor ponad 600 prac magisterskich i licencjackich (w tym dziewięć prac w języku angielskim).

Profesor dr hab. B. Gregor ma duży wkład w rozwój młodej kadry naukowej. Wypromował 19 doktorów (w tym jeden obywatel Niemiec). Był promotorem Doktoratu Honorowego nadanego przez UŁ prof. dr. Lee E. Prestonowi z Uniwersytetu Maryland (USA). Był też recenzentem ośmiu prac habilitacyjnych i jedenastu prac doktorskich.

\section{Odznaczenia, nagrody i wyróżnienia}

Dorobek naukowy, dydaktyczny, organizacyjny i wkład prof. dr. hab. Bogdana Gregora w kształcenie młodej kadry naukowej został doceniony, a wyrazem tego są jego liczne odznaczenia, nagrody i wyróżnienia. Należą do nich:

\section{Odznaczenia}

Medal 25-lecia WSE w Bratysławie (1974)

Honorowa Odznaka SZSP (1979)

Medal za Zasługi dla Studenckiego Ruchu Naukowego (1980)

Złoty Krzyż Zasługi (1986)

Złota Odznaka UŁ (1988)

Medal Komisji Edukacji Narodowej (1993)

Medal „UŁ w Służbie Społeczeństwa i Nauki” (1994)

Medal 50-lecia UŁ (1998)

Krzyż Kawalerski Orderu Odrodzenia Polski (2003)

Honorowa Odznaka „Za Zasługi dla Miasta Łodzi”(2008)

Złoty Medal za Długoletnią Służbę (2011)

\section{Nagrody i wyróżnienia}

Nagroda Ministra Obrony Narodowej (prymus Studium Wojskowego WSE w Poznaniu) - 1965 
Nagrody Ministra:

- dwie nagrody za osiągnięcia naukowe $(1972,1999)$

- jedna za osiągnięcia dydaktyczno-wychowawcze i organizacyjne (1979)

Nagroda naukowa (zespołowa) Prezydenta m. Łodzi (1975)

Wyróżnienie dyplomem w Ogólnopolskim Plebiscycie na Najlepszego

Dydaktyka i Wychowawcę (organizowanego przez Zarząd Główny SZSP) - 1979

Nagroda Sekretarza Naukowego PAN (1980)

Nagrody Rektora Uniwersytetu Łódzkiego:

- jedenaście nagród (indywidualnych i zespołowych) za osiągnięcia naukowo-badawcze $(1975,1976,1978,1979,1985,1986$, 1987, 1989, 1992, 1997, 2003)

- dwadzieścia nagród za osiągnięcia dydaktyczno-wychowawcze i organizacyjne $(1970,1974,1976-1980,1988,1990,1992-$ 2002). 